\title{
Penggunaan Media Seesaw Class pada Kegiatan Belajar dari Rumah Selama Pandemi Covid-19
}

\author{
Anik Twiningsih \\ SD Negeri Laweyan No.54 Kota Surakarta, Surakarta, Indonesia \\ anik.twin@student.uns.ac.id
}

Riwayat artikel: submit: 6 Agustus 2021; revisi: 25 September 2021, diterima: 30 September 2021

\begin{abstract}
ABSTRAK
Penulisan hasil penelitian ini bertujuan untuk mendeskripsikan penggunaan media seesaw class pada kegiatan belajar dari rumah selama pandemi covid-19. Metode penelitian ini menggunakan penelitian kualitatif deskriptif. Teknik pengumpulan data yang digunakan melalui wawancara, observasi, dokumentasi dan portofolio. Subjek penelitian ini adalah siswa kelas 3 SD Negeri Laweyan, Surakarta. Hasil penelitian ini membuktikan bahwa media seesaw class berdampak positif terhadap kegiatan belajar dari rumah pada peserta didik selama pandemic Covid-19. Hal ini ditunjukkan dari berbagai fitur seesaw class yang memudahkan guru dan siswa dalam aktivitas belajar dari rumah selama pandemi covid-19. Aplikasi seesaw class yang dapat diakses melalui handphone andorid tidak hanya memberi kemudahan guru dan siswa dalam berinteraksi, tetapi juga interaksi antarsiswa. Hal inilah yang meningkatkan aktivitas belajar siswa di rumah karena baik guru maupun siswa tidak terpaku oleh waktu. Kata Kunci : Belajar dari rumah, pandemi covid-19, seesaw class
\end{abstract}

\section{ABSTRACT}

The objective of the study is to describe the effectiveness of the media seesaw class in learning from home based in networks (online). This study applied descriptive qualitative research. Data collection techniques used were through interviews, observation, documentation and online portfolios. The subjects of this study were 3rd grade students of SD Negeri Laweyan, Surakarta. The results of this study prove that the media seesaw class has a positive impact on learning from home for students during the Covid-19 pandemic. This is shown by the various seesaw class features that make it easier for teachers and students to learn from home during the Covid-19 pandemic. The seesaw class application that can be accessed via Andorid's cellphone not only makes it easier for teachers and students to interact, but also interactions between students. This is what increases student learning activities at home because both teachers and students are not fixated on time Keywords: Covid-19 pandemic; learning from home; seesaw class

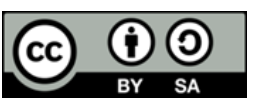

\section{Copyright (C) 2021 The Author(s)}

This is an open access article under the CC BY-SA license.

\section{PENDAHULUAN}

Loncatan perkembangan teknologi di era revolusi industri 4.0 memberikan dampak positif terhadap perkembangan di dunia pendidikan. Dengan perkembangan teknologi di era revolusi industri 4.0 diharapkan memberikan kemudahan - kemudahan dalam peradaban manusia khususnya di peradaban dunia pendidikan. Dengan hadirnya layanan serba dalam jaringan (daring) atau on line, tempat dan waktu tidak menjadikan suatu masalah dalam melaksanakan berbagai aktivitas, begitupun dalam kegiatan pembelajaran. Kehadiran jaringan internet memungkinkan pembelajaran dapat dilakukan dimana saja, kapan saja, maupun dengan siapa saja.

Masa Pandemi Covid-19 memberikan perubahan besar terhadap paradigma pendidikan saat ini. Tidak hanya di negara Indonesia, namun semua negara di dunia ikut merasakan 
Twiningsih, A. (2021). Penggunaan Media Seesaw Class pada Kegiatan Belajar dari Rumah Selama Pandemi Covid-19. Edudikara: Jurnal Pendidikan dan Pembelajaran, 3(6), 163-175.

dampak Pandemi Covid - 19 yang memberikan pengaruh besar terhadap sistem pendidikan. Sistem pendidikan formal yang seharusnya diselenggarakan secara langsung bertatap muka antara peserta didik dan guru di sekolah, saat ini harus dilakukan secara tidak langsung karena dampak Pandemi Covid-19. Selama Pandemi Covid-19 kegiatan pembelajaran di sekolah dilaksanakan secara tidak langsung dari rumah oleh siswa dan guru, lebih tepatnya saat ini diberi istilah kegiatan Belajar Dari Rumah (BDR).

Kegiatan Belajar Dari Rumah (BDR) merupakan tantangan baru bagi guru dalam membangun semangat belajar peserta didik agar tetap semangat belajar dari rumah. Dalam aktivitas kegiatan Belajar Dari Rumah (BDR) guru harus kreatif dalam menciptakan iklim kelas agar tetap kondusif meskipun dalam pelaksanaannya dilakukan secara daring. Menurut Surat Edaran Mendikbud Nomor 4 Tahun 2020 tentang pelaksanaan kebijakan pendidikan dalam masa darurat penyebaran Coronavirus Disease menjelaskan proses Belajar Dari Rumah (BDR) dilaksanakan dengan ketentuan pembelajaran daring/ jarak jauh dilaksanakan untuk memberikan pengalaman belajar yang bermakna bagi siswa, belajar dari rumah dapat difokuskan pada pendidikan kecakapan hidup, aktivitas dan tugas pembelajaran Belajar Dari Rumah (BDR) dapat bervariasi antarsiswa, sesuai minat dan kondisi masing - masing. Bertolak dari penjelasan Mendikbud tersebut dapat ditarik benang merah bahwa pelaksanaaan Belajar Dari Rumah (BDR) bersifat fleksibel dan kondisional sesuai kondisi peserta didik. Selama kegiatan Belajar Dari Rumah (BDR) pembelajaran dapat dilaksanakan dengan model pembelajaran jarak jauh, guru diberikan kewenangan untuk menentukan strategi dan media pembelajaran dalam mengelola kelasnya. Guru dapat mengelola kelasnya baik secara daring maupun luring. Ruang kelas yang selama ini sebagai sarana ruang belajar berinteraksi langsung antar guru dan peserta didik, saat ini ruang kelas tidak hanya berupa ruang kelas nyata namun ruang kelas maya pun bisa terjadi aktivitas belajar antara guru dan peserta didik. Pengelolaan kelas secara daring dapat memanfaatkan media belajar yang menarik serta memperhatikan kondisi peserta didik.

Ruang kelas baik itu ruang kelas luring maupun daring merupakan salah satu media belajar yang menentukan keberhasilan kegiatan pembelajaran. Menurut Kaltsum (2017) media pembelajaran diartikan sebagai segala sesuatu yang dapat menyampaikan dan menyalurkan pesan dari sumber secara terencana sehingga tercipta lingkungan belajar yang kondusif di mana penerimanya dapat melakukan proses belajar secara efektif dan efisien. Media belajar harus praktis dalam penggunaannya sehingga peserta didik bersama orangtua lebih mudah menerima pesan - pesan dari guru yang berupa berbagai sumber belajar baik itu berupa gambar, video, ataupun tautan yang mendukung proses kegiatan pembelajara. Media pembelajaran di masa Pandemi dapat ditentukan guru dengan memperhatikan keefektifan media belajar yang akan digunakan, setidaknya dapat meningkatkan kualitas dan kuantitas belajar peserta didik agar tetap semangat belajar meskipun pembelajaran dilaksanakan dari rumah dengan system pembelajaran jarak jauh.

Seesaw class learning management system merupakan salah satu media yang dapat digunakan guru dalam mengelola pembelajaran berbasis dalam jaringan. Seesaw class Learning Management System memberikan kemudahan bagi peserta didik dalam kegiatan Belajar Dari Rumah (BDR) karena dengan Seesaw class Learning Management System dapat menyelesaikan project - project pembelajaran dengan mudah dan praktis. Menurut Enrico (2018) Seesaw merupakan platform pada internet yang dikembangkan Graham, Sjogreen, dan Lin untuk membantu peserta didik dalam mengerjakan tugas portofolio dalam bentuk tulisan, gambar, atau suara. Seesaw merupakan platform yang masih tergolong baru berkembang di internet, sehingga menjadi tantangan bagi guru untuk mengaplikasikan sebagai sarana asesmen elektronik. Selain itu, Seesaw memiliki fasilitas pemberian feedback tulisan atau lisan sebagai sarana evaluasi penilaian secara elektronik. Media seesaw class learning management system juga mendukung terkait keterlaksanaan pembelajaran abad 21. Hafriyani menyebut bahwa 
Twiningsih, A. (2021). Penggunaan Media Seesaw Class pada Kegiatan Belajar dari Rumah Selama Pandemi Covid-19. Edudikara: Jurnal Pendidikan dan Pembelajaran, 6(3), 163-175

dalam menghadapi arus globalisasi, seluruh sektor di Indonesia berusaha agar mampu mewujudkan generasi emasi 2045 yang salah satunya melalui pembelajaran abad 21 (Harfiyani, 2018). Pembelajaran abad 21 yang terkenal dengan kompetensi untuk berkomunikasi, berkolaborasi, berpikir kritis dan pemecahan masalah, dan mencipta. Media seesaw class learning management system menjadi upaya guru dalam menciptakan pembelajaran jarak jauh yang tetap mengedepankan pada pengembangan keterampilan berpikir peserta didik.

Aplikasi media seesaw class memberikan kemudahan bagi guru dan peserta didik saat kegiatan pembelajaran, khususnya pada masa - masa pandemi, karena dengan menggunakan media seesaw class learning management system peserta didik lebih mudah mengirimkan tugas - tugas yang diberikan oleh guru, selain itu tugas - tugas tersebut menjadi terorganisasi dengan baik. Peserta didik dapat mengirimkan berbagai bentuk tugas yang diberikan oleh guru, bak itu berupa dokumen, poto, video dengan mudah dan praktik. Kehadiran media seesaw class bagi guru sangat memberikan manfaat dalam menyampaikan berbagai tugas tugas untuk peserta didik selama belajar dari rumah dengan system pembelajaran jarak jauh secara daring. Guru menjadi lebih mudah menyusun dan mengarsipkan portofolio tugas tugas peserta didik yang telah diberikan serta lebih mudah dalam memberikan penilaian terhadap tugas siswa. Oleh karenanya, penulis membuat artikel yang berjudul "Penggunaan Media Seesaw Class pada Kegiatan Belajar Dari Rumah Selama Pandemi Covd-19". Dengan harapan dapat memberikan sumbangsih pemikiran dan pengalaman terkait kegiatan belajar dari rumah kepada rekan guru maupun penggiat pendidikan yang lainnya.

\section{METODE}

Penelitian ini menggunakan jenis penelitian kualitatif deskriptif dengan pendekatan kepustakaan. Tujuan penelitian ini adalah mendeskripsikan kegiatan Belajar Dari Rumah (BDR) secara daring yang telah dilaksanakan oleh guru pada siswa kelas tiga di SD Negeri Laweyan No.54 Kota Surakarta selama masa Pandemi Covid-19 dengan menggunakan media belajar seesaw class learning management system. Penelitian ini mengkaji kepustakaan karena lebih efektif digunakan selain itu dalam teknik pengumpulan data lebih mudah didapat yaitu dengan melalui sumber data berupa dokumen, berita, jurnal, buku dan sebagainya. Menurut ahli penelitian kepustakaan Sugiyono (2018: 3) yang menyatakan bahwa "metode penelitian kualitatif terutama digunakan untuk memperoleh data yang kaya, informasi yang mendalam tentang isu atau masalah yang akan dipecahkan".

Teknik pengumpulan data yang digunakan dalam penelitian adalah dengan teknik wawancara, observasi dengan mengkaji aktivitas siswa secara daring, data portofolio siswa dan dokumentasi selama pembelajaran berlangsung secara daring serta hasil refleksi pada kegiatan akhir pembelajaran secara daring. Wawancara dilakukan dengan melakukan percakapan kepada peserta didik terkait kegiatan Belajar Dari Rumah (BDR) untuk mendapatkan informasi data yang tepat dari narasumber selama penelitian khususnya pada dampak Covid-19 dalam kegiatan Belajar Dari Rumah (BDR) siswa kelas 3 di SD Negeri Laweyan No.54 Kota Surakarta. Data portofolio siswa dan dokumentasi selama pembelajaran berlangsung secara daring serta hasil refleksi pada kegiatan akhir pembelajaran secara daring diambil oleh guru melalui monitoring kegiatan pembelajaran harian yang dilakukan pada kurun waktu tertentu sebagai bahan evaluasi terhadap keefektifan media Seesaw class Learning Management System. Kemudian, studi kepustakaan juga dilakukan untuk memperoleh data secara teoritis terkait media seesaw class learning management system dalam kegiatan pembelajaran melalui kajian penelitian - penelitian yang relevan yang pada akhirnya dikuatkan dengan penelitian yang telah dilakukan guru pada siswa kelas 3 SD Negeri Laweyan No.54 Kota Surakarta. 
Twiningsih, A. (2021). Penggunaan Media Seesaw Class pada Kegiatan Belajar dari Rumah Selama Pandemi Covid-19. Edudikara: Jurnal Pendidikan dan Pembelajaran, 3(6), 163-175.

\section{HASIL DAN PEMBAHASAN \\ Hasil Penelitian \\ Implementasi Media Seesaw Class Learning Management System \\ Tahap Persiapan}

Persiapan yang dilakukan guru sebelum pelaksanaan kegiatan Belajar Dari Rumah (BDR) adalah melakukan koordinasi bersama orangtua siswa melalui media whatsapp group. Kemudian guru memberikan teknik langkah - langkah cara mengunduh aplikasi seesaw class pada menu play store yang ada pada android dan cara registrasi untuk mendapatkan akun siswa pada aplikasi seesaw class. Cara mengunduh dan registrasi aktivasi akun aplikasi seesaw class adalah sebagai berikut :

1. Carilah aplikasi seesaw class pada play store yang ada pada android

2. Unduh aplikasi seesaw class setelah terunduh buka dan lakukan registrasi sebagai guru atau siswa (disesuaikan dengan kebutuhan )

3. Kemudian melakukan registrasi dengan menggunakan alamat email yang dimiliki dan isi ketentuan - ketentuannya

4. Setelah aktivasi akun kunjungi kode kelas yang diberikan oleh guru, apabila sebagai siswa

Setelah masing - masing orang tua peserta didik sudah melakukan unduh aplikasi dan registrasi akun sebagai siswa, guru memberikan penjelasan dan pengarahan kepada orangtua tentang cara mengunjungi kode kelas sesuai yang ditentukan oleh guru. Setelah semua orangtua mengunjungi kode kelas yang ditentukan guru, kemudian menunggu notifikasi tugas - tugas di setiap kode kelas yang telah ditentukan guru.

\section{Tahap Pelaksanaan}

Pada tahap pelaksanaan kegiatan Belajar Dari Rumah (BDR) dengan menggunakan media seesaw class, guru membagikan kode kelas dengan membaginya di setiap sub tema, sehingga setiap tema terbagi menjadi 4 sub tema, misal : tema 1 terbagi menjadi 4 sub tema, disana ada 4 kode kelas yaitu : kode kelas tema 1 sub tema 1, kode kelas tema 1 sub tema 2, kode kelas tema 1 sub tema 3, kode kelas tema 1 sub tema 4. Pada penelitian ini, untuk menggali lebih dalam terkait penggunaan media seesaw selama pembelajaran di semester 1 , sehingga di sama ada 16 sub tema yang memiliki masing - masing kode kelas untuk mengirimkan tugas siswa. Berikut contoh tampilan kode - kode kelas sub tema 1 pada akun guru yang sudah terkoneksi dengan akun siswa :

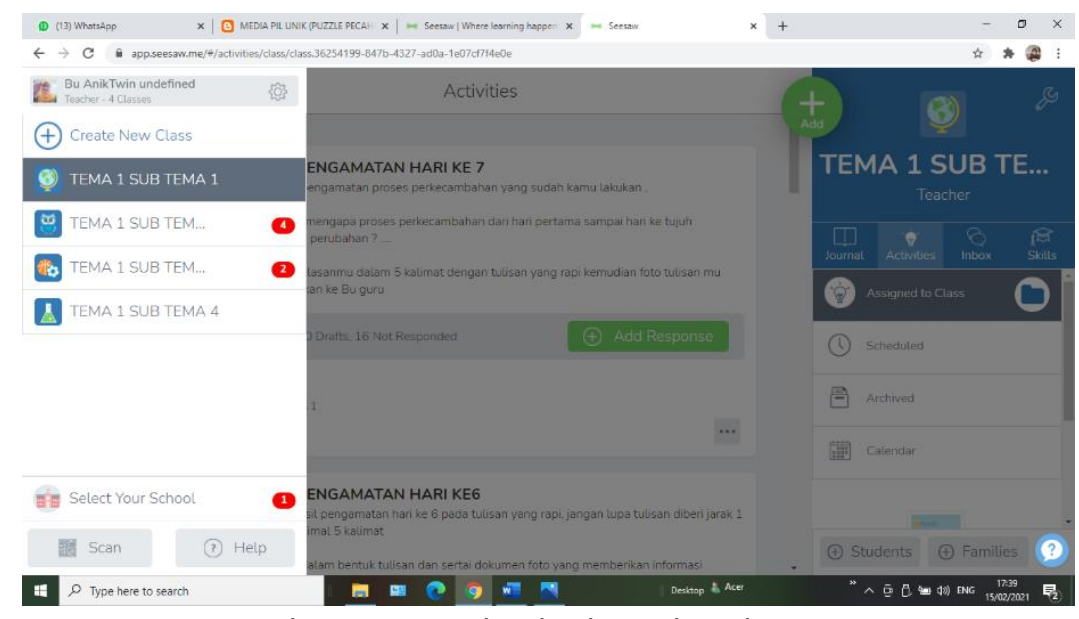

Gambar 1. Tampilan kode pada sub tema 1

Setelah setiap siswa memperoleh kode kelas dan masuk pada kode kelas masing - masing guru membagikan tugas sesuai kode kelas yang ditentukan, guru mengirim dan membagikan 
tugas kepada siswa setiap hari sesuai dengan jam masuk sekolah yaitu 5 hari sekolah dari hari Senin - Jumat. Setelah guru mengirim tugas pada kode kelas masing - masing akan ada notifikasi pemberitahuan di akun siswa bahwa ada tugas yang harus diselesaikan. Berikut contoh tugas siswa yang dibagikan guru melalui akun guru media seesaw class :

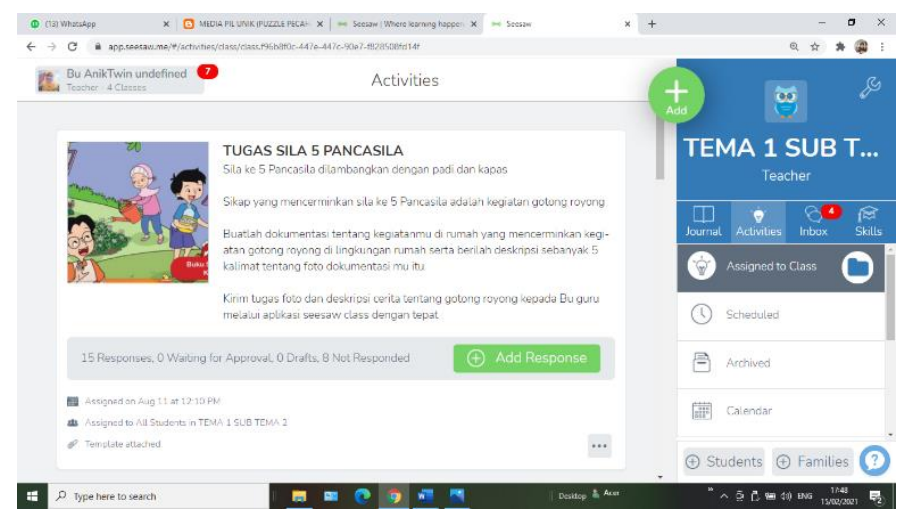

Gambar 2. Contoh tugas siswa yang dibagikan guru

Pada tahap berikutnya, akan muncul tugas - tugas yang harus dikerjakan siswa. Sebelum tugas - tugas dikerjakan dan dikumpulkan oleh siswa, guru juga dapat mengecek kelengkapan siswa yang sudah dan yang belum masuk sesuai kode kelas tugas yang diberikan. Pada akun guru akan muncul siswa - siswa yang sudah masuk kode kelas, sehingga guru dapat menginformasikan kembali kepada siswa dan orangtua bagi yang belum masuk sesuai kode kelas agar segera masuk kode kelas yang sudah ditentukan. Berikut tampilan yang menunjukkan siswa - siswa yang sudah masuk kode kelas dan siap menerima tugas dari guru :

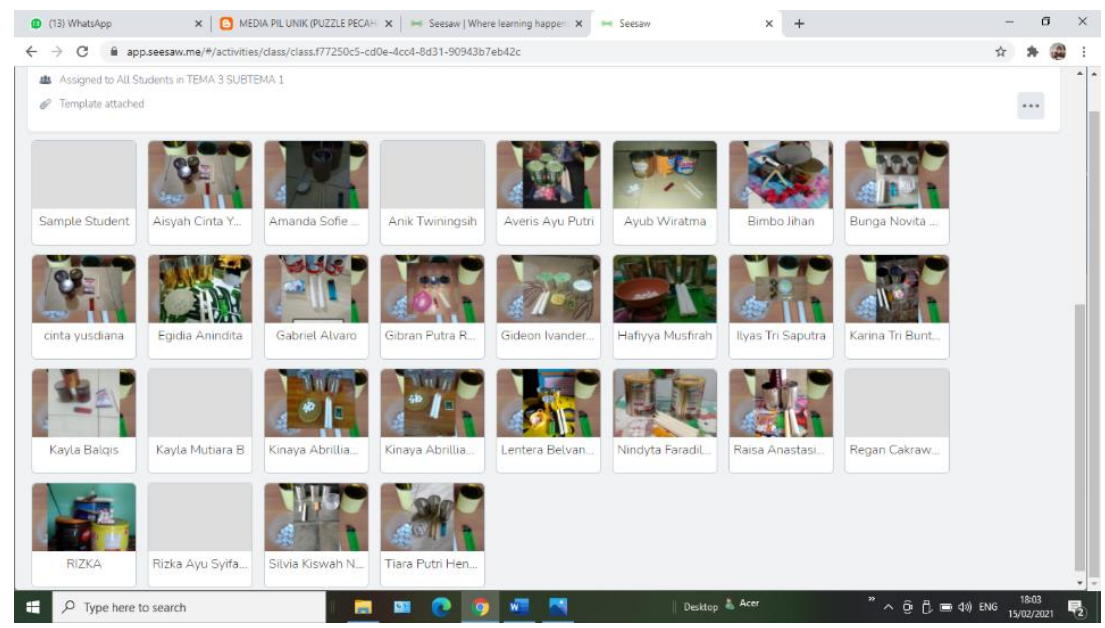

Gambar 3. Tampilan siswa yang masuk kode kelas

Berdasarkan tampilan gambar di atas dapat dijelaskan bahwa, ada 28 siswa yang sudah masuk kelas. Disini terlihat bahwa ada 24 siswa yang sudah merespon tugas guru dan telah mengirimkan tugas dengan tepat sesuai kode kelas, dan ada 4 siswa lainnya yang sudah masuk kelas namun belum merespon tugas guru serta belum mengirimnya. Dengan media seesaw class guru lebih mudah mengontrol tugas - tugas siswa dan melakukan monitoring terhadap perkembangan kegiatan siswa di kelas maya secara daring.

Selama pemberian tugas, guru menugaskan siswa dengan mengirim foto dokumentasi hasil pekerjaan siswa serta video hasil praktik tugas siswa. Hal ini dilakukan guru agar guru memiliki bukti autentik hasil pekerjaan siswa, selain itu guru juga dapat memastikan bahwa 
Twiningsih, A. (2021). Penggunaan Media Seesaw Class pada Kegiatan Belajar dari Rumah Selama Pandemi Covid-19. Edudikara: Jurnal Pendidikan dan Pembelajaran, 3(6), 163-175.

tugas tersebut hasil pekerjaan siswa, bukan hasil pekerjaan orang lain. Berikut dokumentasi guru hasil tugas yang telah dikirim siswa melalui kode kelas yang berupa video :

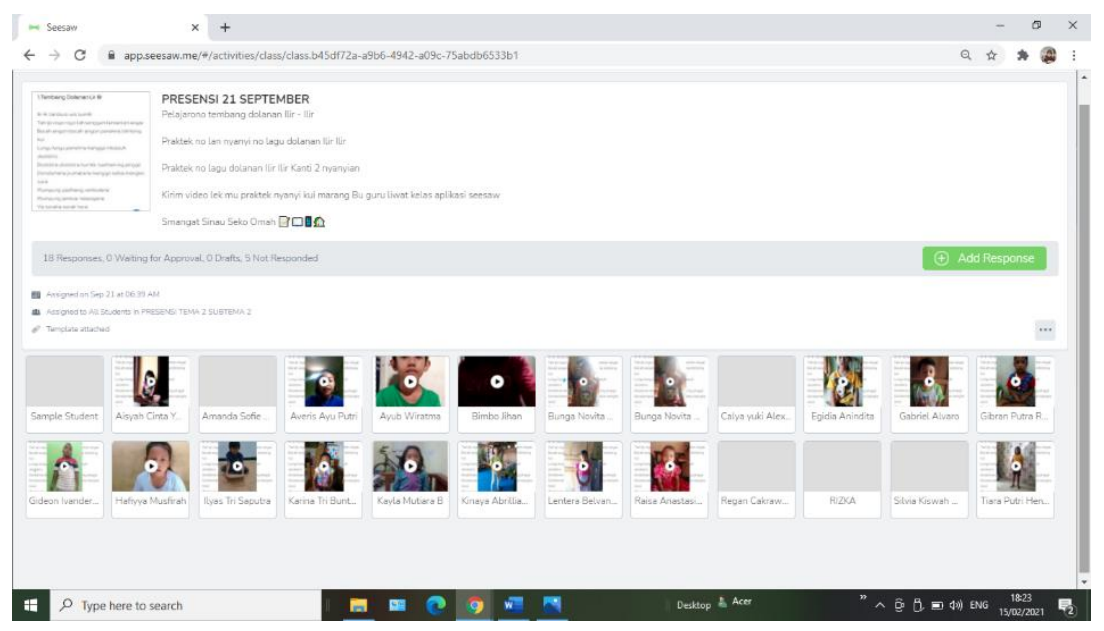

Gambar 4. Hasil tugas yang dikirim siswa

\section{Tahap Pengamatan}

Pengamatan yang dilakukan guru selama kegiatan Belajar Dari Rumah (BDR) dengan menggunakan seesaw class learning management system meliputi pengamatan tentang keaktifan siswa dalam kelas maya, hal ini dibuktikan dengan keaktifan siswa dalam mengumpulkan tugas - tugas oleh guru. Selain itu keaktifan yang dinilai oleh guru antara lain keaftifan dalam merespon feedback yang diberikan guru dalam memberikan refleksi terhadap tugas yang telah kerjakan siswa. Nilai keaktifan ini akan dianalisis guru dalam bentuk rubrik penilaian sikap yang nanti akan menghasilkan data nilai sikap harian. Nilai sikap ini nanti dijadikan sebagai bahan pertimbangan pertimbangan apabila ada kesamaan perolehan nilai pengetahuan dari beberapa siswa.

Kemudian, guru juga mengamati bagaimana keterampilan siswa dalam mengerjakan tugas, hal ini nanti akan dianalisis guru dalam bentuk rubrik penilaian yang berupa rubrik penilaian keterampilan. Keterampilan ini disesuaikan dengan tingkatan C1 - C6 sesuai taksonomi Bloom, yaitu C1 (mengingat), C2 (memahami), C3 ( mengaplikasikan), C4 (menganalisis), C5 (mengevaluasi), dan C6 (mencipta).

Sumber data guru dalam menentukan tingkat keterampilan siswa diperoleh dari tugas tugas siswa yang telah dikirim baik melalui gambar, video, atau dokumen tulisan yang sudah dikerjakan oleh siswa kemudian dianalisis guru dengan menggunakan skala likert untuk menjadikan nilai kualitatif siswa menjadi nilai kuantitafif siswa. Skala likert yang digunakan guru untuk mengukur keterampilan siswa disetiap tingkatan nilaia keterampilan yaitu sangat baik (skor 3), baik (skor 2), dan kurang baik (skor 1). Dengan menggunakan skala nilai akan memudahkan guru memberikan nilai kepada siswa dalam bentuk angka. Data yang semula berupa tulisan dapat dijadikan data angka dengan mengubah data kualitatif menjadi data kuantitatif. Berikut contoh penilaian guru dalam memberikan nilai terhadap keterampilan terhadap hasil percobaan yang sudah dilakukan siswa : 
Twiningsih, A. (2021). Penggunaan Media Seesaw Class pada Kegiatan Belajar dari Rumah Selama Pandemi Covid-19. Edudikara: Jurnal Pendidikan dan Pembelajaran, 6(3), 163-175

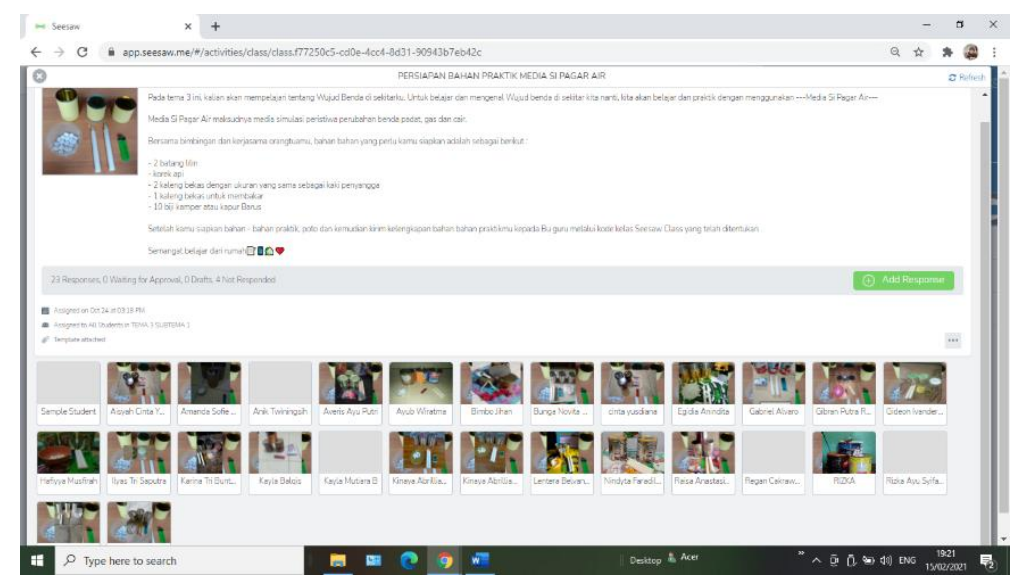

Gambar 5: Laporan hasil persiapan bahan yang dikirim siswa

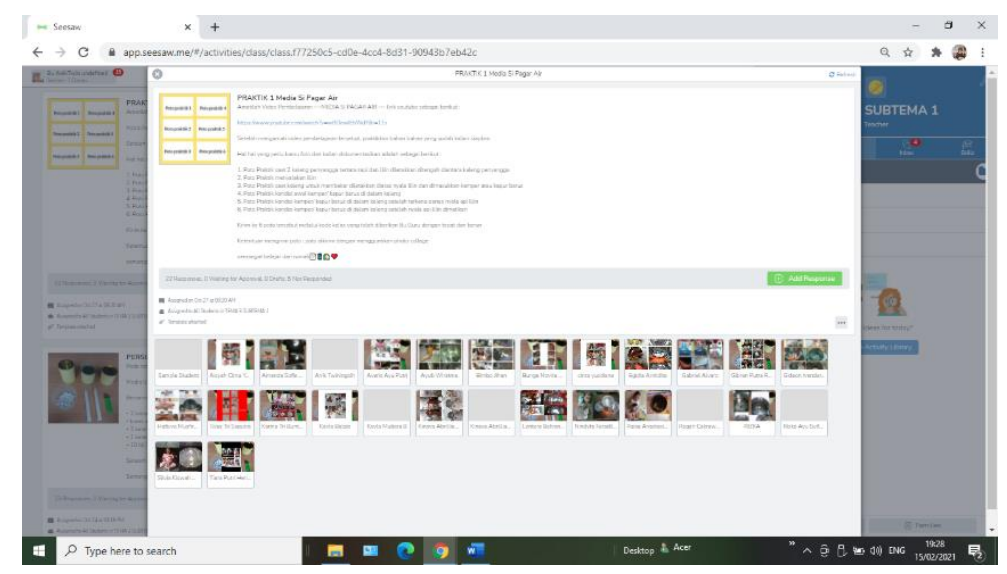

Gambar 6: laporan hasil percobaan langsung siswa

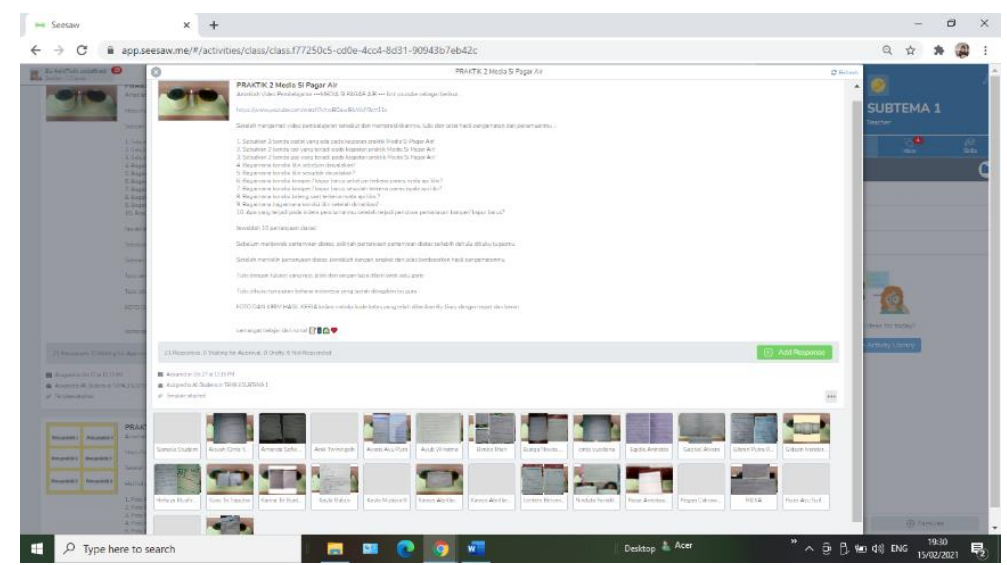

Gambar 7: Laporan Hasil Percobaan Siswa secara Tertulis

Dari ketiga hasil dokumentasi siswa di atas dapat dijelaskan bahwa guru dapat mengambil data sebagai bahan penilaian keterampilan sekaligus pengetahuan. Hal ini dapat dilakukan dengan mengamati hasil pekerjaan siswa yang sudah dikirimkan melalui kode kelas yang berupa video ataupun gambar tugas. Melalui pengamatan hasil video atau gambar tugas siswa, guru dapat menentukan dan memberikan penilaian baik secara kualitatif maupun secara kuantitatif. Penilaian kualitatif yang diberikan dapat dijadikan nilai kuantitatif dengan menggunakan metode skala likert yang sudah ditentukan. Dengan demikian akan 
Twiningsih, A. (2021). Penggunaan Media Seesaw Class pada Kegiatan Belajar dari Rumah Selama Pandemi Covid-19. Edudikara: Jurnal Pendidikan dan Pembelajaran, 3(6), 163-175.

mempermudah guru melakukan evaluasi dan penilaian terhadap hasil pekerjaan siswa yang telah dilakukan melakui kegiatan Belajar Dari Rumah (BDR).

Dengan menggunakan metode penilaian skala likert guru tidak hanya dapat menilai satu aspek keterampilan saja, namun guru dapat mengukur keterampilan siswa dalam berbagai aspek, seperti keterampilan berpikir, termasuk dalam keterampilan yang diamanahkan keterampilan abad 21 yaitu keterampilan berpikir kritis ( critical thinking skill), keterampilan berpikir kreatif (crative thinking skill), keterampilan berkolaborasi (collaborative thinking skill), dan keterampilan berkomunikasi (communicative thinking skill). Dengan demikian tidak ada alas an guru mengalami kesulitan dalam melakukan penilaian proses meskipun pembelajaran dilakukan dengan sistem Pembelajaran Jarak Jauh (PJJ) melalui kegiatan Belajar Dari Rumah (BDR)

\section{Tahap Refleksi}

Refleksi dalam pelaksanaan penelitian adalah untuk mengkaji ulang hal - hal yang sudah dilaksanakan dalam kegiatan dan kemudian diadakan perbaikan dengan melakukan kegiatan tindak lanjut. Refleksi dilakukan dengan mengkaji seluruh kegiatan yang sudah dilakukan berdasarkan data yang telah terkumpul, dan kemudian dievaluasi yang bertujuan untuk menyempurnakan penelitian yang akan dilaksanakan berikutnya.

\section{Hasil Penilaian Siswa terhadap Media Seesaw class Learning Management System}

Dengan memperhatikan pembelajaran jarak jauh yang telah dilakukan peneliti. Berbagai macam media pembelajaran daring sudah pernah dicoba seperti google meet, zoom meeting, maupun whats app group. Oleh karenanya, peneliti menggali penilaian siswa terhadap media baru yaitu seesaw class learning management system yang digunakan selama kegiatan belajar dari rumah (BDR) di masa pandemi covid-19. Berikut ini uraian hasilnya:

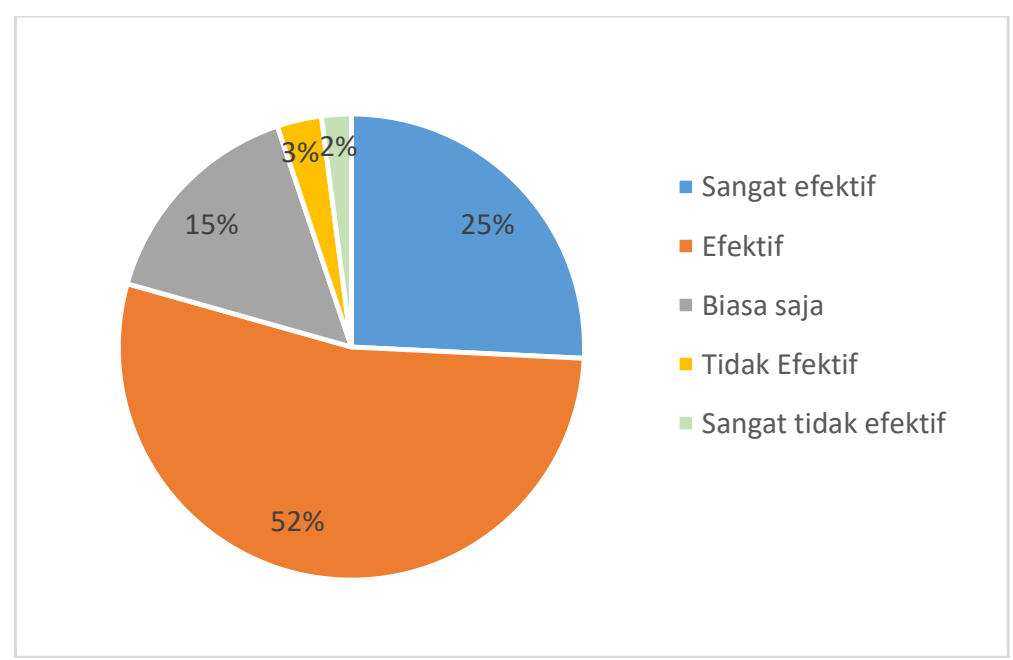

Gambar 8. Hasil penilaian siswa terhadap media seesaw class learning management system

Berdasarkan grafik pada gambar 8 di atas menunjukkan bahwa media seesaw class dinilai efektif oleh siswa saat mereka melakukan kegiatan belajar dari rumah. Hanya $3 \%$ yang menilai tidak efektif dan $2 \%$ saja yang menilai sangat tidak efektif. Berdasarkan hasil wawancara mengungkapkan bahwa handphone yang digunakan hanya menyisakan sedikit memori untuk aplikasi seesaw class sehingga berpengaruh pada kelancaran loading pengguna. Selain itu, kekuatan jaringan internet juga menjadi faktor kelancaraan penggunaan media seesaw. Hampir sebagian besar siswa menilai bahwa media seesaw efektif untuk dijadikan platform media mereka selama kegiatan belajar dari rumah. Peserta didik merasa ada platform chating 
Twiningsih, A. (2021). Penggunaan Media Seesaw Class pada Kegiatan Belajar dari Rumah Selama Pandemi Covid-19. Edudikara: Jurnal Pendidikan dan Pembelajaran, 6(3), 163-175

yang baru namun lebih akademis. Penggunaan whats app group yang juga digunakan oleh gurupun dinilai menggangu aktivitas belajar dari rumah karena aktivitas sehari-hari orang tua atau wali peserta didik bercampur dengan notifikasi pembelajaran daring dari guru. Oelh karenanya, media seesaw ini disambut baik oleh peserta didik maupun orang tua atau wali. Hal-hal yang menjadi kekurangan dalam penggunaan media seesaw ini akan penulis tindak lanjuti dengan rekan sejawat dan juga orang tua atau wali sebagai partner guru selama kegiatan belajar dari rumah.

\section{Tindak Lanjut Pengembangan Media Seesaw class Learning Management System}

Tindak lanjut dari implementasi dari penerapan media Seesaw class Learning Management System ini adalah guru melakukan pengimbasan hasil dari penerapan media seesaw class kepada rekan - rekan sesama guru dengan mengunggah kegiatan pembelajaran seesaw class di blog atau website sehingga dapat di simak oleh khalayak umum sebagai bentuk publikasi juga. Selain itu, guru juga menghimbau kepada orang tua atau wali siswa terkait halhal teknis yang dapat memberi kelancaraan penggunaan media seesaw di handphone android.

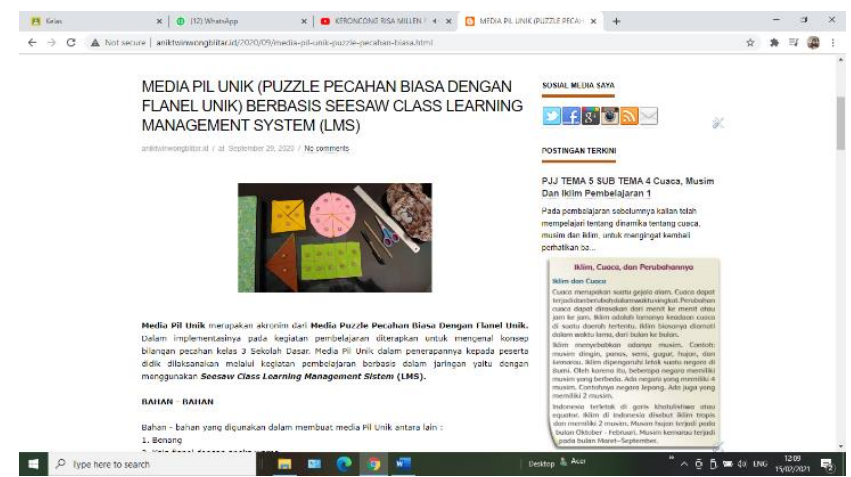

Gambar 9. Unggahan penggunaan media seesaw class di blog

Selain itu, bentuk tindak lanjut dari penggunaan media seesaw class adalah dengan membuat bukti laporan tertulis sebagi hasil praktik pada kegiatan pembelajaran Belajar Dari Rumah (BDR) selama pandemi Covid-19. Dengan membuat laporan bukti fisik telah melakukan praktik baik akan memberikan juga motivasi bagi rekan - rekan guru agar lebih meningkatkan semangat membuat inovasi pembelajaran sehingga berdampak positif terhadap peningkatan pengetahuan, sikap dan keterampilan siswa.

\section{Pembahasan}

Berdasarkan hasil penelitian yang telah ditulis, dapat diketahui bahwa media seesaw class dapat menjadi alternatif bagu guru dalam melaksanakan pembelajaran jarak jauh (PJJ). Media seesaw class ini juga memberikan kemudahan bagi guru maupun siswa untuk tetap berkegiatan karena model seesaw class ini dilakukan secara asynchronous. Divayana, Heryanda, dan Suyasa mengemukakan bahwa asynchronous merupakan kegiatan pembelajaran yang dilakukan antara guru dengan siswa dalam waktu yang tidak bersamaan, guru mendistribusikan bahan ajar yang kemudian dapat diakses oleh siswa kapanpun dan dimanapun mereka berada (Divayana, Heryanda, \& Suyasa, 2020: 308). Kelebihan media seesaw ini juga diungkapkan oleh Qotimah (2018) bahwa seesaw merupakan platform pembelajaran yang memungkinkan setiap peserta didik untuk memiliki jurnal pembelajaran kolaboratif. Guru dapat berbagi konten langsung berupateks, gambar, video, gambar dan tautan yang dapat dilihat siswa pada android/handphone/iPhone mereka secara asynchronous. Selain itu, siswa juga dapat membangun atau merancang kreasi dan karya-karya inovatif sesuai kompetensi kinerja yang disepakati bersama dengan guru mata pelajaran. 
Twiningsih, A. (2021). Penggunaan Media Seesaw Class pada Kegiatan Belajar dari Rumah Selama Pandemi Covid-19. Edudikara: Jurnal Pendidikan dan Pembelajaran, 3(6), 163-175.

Penggunaan media seesaw pada penelitian ini juga turut mendukung pembelajaran abad 21 yang mana siswa akrab dengan teknologi. Pembelajaran daring selama pandemi covid-19 juga memberikan keleluasaan waktu belajar bagi siswa dimanapun dan kapanpun. Terkait hal ini, Dewi mengungkap bahwa lingkungan belajar dan karakteristik siswa menjadi indikator keberhasilan pembelajaran daring (Dewi, 2020). Pada penelitian ini, semua siswa telah mempunyai handphone android sehingga mereka juga merasa bahwa penggunaan media seesaw ini dinilai efektif untuk kegiatan belajar dari rumah selama pandemi covid-19 (lihat grafik pada gambar 8 ).

Kehadiran media seesaw membuat peserta didik merasa memiliki platform chating yang baru sehingga membuat mereka antusias setiap mengerjakan tugas dari guru. Penggunaan whats app group yang juga digunakan oleh gurupun dinilai menggangu aktivitas belajar karena aktivitas sehari-hari orang tua atau wali peserta didik bercampur dengan notifikasi pembelajaran daring dari guru. Oleh karenanya, penggunaan media seesaw selain disambut baik oleh peserta didik maupun orang tua atau wali juga meningkatkan keefektifan kegiatan belajar dari rumah yang juga ditunjukkan oleh antuasisme mereka dalam mengikuti setiap kegiatan pada media seesaw class. Antusiasme inilah yang mampu menumbuhkan motivasi belajar peserta didik selama pandemi covid-19. Dengan motivasi inilah yang juga sangat berpengaruh terhadap prestasi belajar (Prananda \& Hadiyanto, 2019:911).

Kegiatan belajar dari rumah melalui media seesaw ini merupakan upaya peneliti selaku guru dalam melatih kemandirian belajar peserta didik sekaligus mengenalkan berbagai macam teknologi yang dapat dimanfaatkan sebaga media pembelajaran daring. Sobron AN dkk menyebut bahwa pembelajaran daring yang diterapkan selama pandemi covid-19 menjadi tantangan bagi guru dalam memberikan rangsangan yang mampu membuat siswa merasa terlibat dalam proses pembelajaran (A. N, Bayu, Rani, \& Meidawati, 2019). Meskipun kehadiran sosial dalam pembelajaran daring sangatlah kurang, Tantri menemukan bahwa sebanyak $73 \%$ responden merasa percaya diri saat pembelajaran jarak jauh dalam komunikasi online ataupun bentuk diskusi online (Tantri, 2018).

Apapun platform media yang digunakan, pembelajaran daring memnuntut partisipasi aktif dari peserta didik. Apalagi pada sekolah dasar, orang tua atau walilah yang menjadi partner guru dalam menjamin keberhasilan pembelajaran jarak jauh. Sobri, dkk mengungkapkan bahwa pembelajaran daring seharusnya tetap membangun pengetahuan, kolaborasi, pemecahan masalah, dan media website (Sobri, Nursaptini, \& Novitasari, 2020). Meskipun pada kenyataannya kolaboratif peserta didik sekolah dasar pada penelitian ini lebih tertuju pada kolaborasi antara orang tua atau wali dengan anaknya. Hal ini tidak terlepas dari pandemi covid-19 yang membuat peneliti berpikir ulang jika akan mengadakan kerja kelompok siswa.

Penggunaan media seesaw juga lebih memudahkan guru dalam memberi instruksi tugastugas yang harus dikerjakan peserta didik, utamanya tugas yang berbasis proyek. Guru dan peserta didik dapat berkomunikasi secara asynchrounous. Arahan tugas dari guru juga lebih jelas jika menggunakan media seesaw. Hal ini terlihat pada grafik hasil penilaian siswa di gambar 8 yang menunjukkan bahwa 52\% peserta didik menilai media seesaw sangat efektif dan $25 \%$ peserta didik menilai media seesaw efektif dalam kegiatan belajar dari rumah. Hal ini diperkuat oleh Qotimah yang menemukan bahwa media seesaw sangat memberikan manfaat sebagai digital portofolio peserta didik. Fitur kelas digita seesaw membuat guru dapat memasukkan pesan, materi, foto, ataupun video yang berkaitan dengan materi. Begitu pula peserta didik yang dapat menggunggah tugas-tugasnya ke dalam kelas digital seesaw, bahkan dapat dijadikan sebagai blog (Qotimah, 2018). Media seesaw juga melibat tiga pihak yang sangat berperan yaitu guru, peserta didik, dan orang tua atau wali peserta didik.

Hasil penilaian siswa yang menunjukkan bahwa media seesaw merupakan platform media yang efektif untuk kegiatan belajar dari rumah (lihat grafik pada gambar 8) menunjukkan bahwa hadirnya aplikasi ini menumbuhkan motivasi siswa. Ebrahimzadeh dan Alavi menyebut 
Twiningsih, A. (2021). Penggunaan Media Seesaw Class pada Kegiatan Belajar dari Rumah Selama Pandemi Covid-19. Edudikara: Jurnal Pendidikan dan Pembelajaran, 6(3), 163-175

bahwa motivasi merupakan penentu perilaku yang sangat penting karena dapat menyebar luas ke berbagai aspek, misalnya individu akan memilih tindakan tertentu, tekun terhadap tugas, dan berupaya untuk menyelesaikan tugas tersebut. Hal ini ditentukan oleh motivasi yang hadir dalam dirinya (Ebrahimzadeh \& Alavi, 2017). Motivasi belajar juga sangat mempengaruhi keaktifan dan hasil belajar peserta didik (Tegeh, Pratiwi, \& Simamora, 2019). Sejalan dengan hal ini, Widiastuti dan Sumantri menyebut bahwa motivasi juga tidak hanya bersumber pada internal seseorang, motivasi dapat bersumber dari faktor eksternal seseorang. Motivasi yang semakin kuat juga akan semakin menunjukkan kualitas perilaku yang ditampilkan, baik dalam konteks belajar, bekerja atapun kehidupan lainnya (Widiastiti \& Sumantri, 2020). Penggunaan media seesaw yang disambut baik oleh peserta didik maupun orang tua menunjukkan bahwa variasi penggunaan platform media kegiatan belajar dari rumah dapat membuat peserta didik tidak bosan. Mereka antusias dalam mengenal platform media yang baru karena selama ini yang mereka gunakan hanyala whats app group, google meeting, maupun zoom meeting.

Penggunaan media seesaw class learning management system juga selaras dengan revolusi pembelajaran. Komara menyebut bahwa revolusi pembelajaran memiliki berbagai prinsip yaitu harus berpijak pada pilar-pilar active learning, creative learning, effective learning, dan joyfull learning (Komara, 2018). Revolusi pembelajaran ini sering disebut dengan pembelajaran abad 21. Martini mengemukakan bahwa abad 21 membuat semua sektor harus mampu mengimbangi perkembangan zaman pada semua situasi termasuk situasi pandemi covid-19 (Martini, 2018) yang masih terjadi hingga saat ini. Fajri juga mengungkapkan bahwa pembelajaran abad 21 memberikan gambaran nyata terkait sekolah yang ideal. Ideal yang dimaksud yaitu pembelajaran yang memberikan pengalaman nyata dan berharga bagi peserta didik (Fajri, 2017). Pembelajaran abad 21 juga mencerminkan kondisi dan situasi yang akan datang. Penggunaan media seesaw class learning management system selama kegiatan belajar dari rumah di masa pandemi covid-19 menunjukkan bahwa belajar tidak terbatas pada ruang kelas yang dibatasi oleh tembok dan gedung sekolah, belajar yang merdeka justru mampu memberi akses yang terbuka bagi peserta didik dalam belajar dimanapun dan kapanpun.

Sehubungan dengan pelaksanaan pembelajaran daring, Ningsih menyebut bahwa ada beberapa hal terpenting yang harus diperhatikan dalam pembelajaran online yaitu isi materi yang disajikan harus relevan dengan tujuan khusus pembelajaran, metode yang digunakan mampu melatih dan membantu pembelajar dalam belajar, media yang digunakan mampu menyajikan isi materi, dan dapat membangun serta mengembangkan pengetahuan dan keterampilan baru sesuai tujuan belajar serta peningkatannya (Ningsih, 2020). Sejalan dengan hal ini, pelaksanannya juga memerlukan perangkat-perangkat mobile seperti smartphone atau hp android dan laptop atau komputer yang digunakan dalam mengakses pembelajaran online (Sadikin \& Hamidah, 2020). Sadikin dan Hamidah juga menyebut bahwa pembelajaran daring juga mampu menghubungkan peserta didik dengan sumber belajarnya secara langsung ataupun tidak langsung. Oleh karenanya, pada masa pembelajaran jarak jauh perlu mempertimbangkan berbagai faktor dalam komunikasi belajar seperti konsumsi kuota data, kemudahan pengguna, kondisi infrastruktur jaringan, dan kesesuaian dengan aktivitas pembelajaran (Fahmi, 2020). Fahmi juga menyebut bahwa media komunikasi yang sering sekali digunakan oleh guru dan peserta didik yang memiliki preferensi tinggi yaitu whats app, zoom meeting, goole meet, microsoft team, google classroom, google form, dan quizziz. Oleh karenanya, penggunaan media seesaw class learning management system masih sangat jarang digunakan, padahal memberikan fitur-fitur yang lebih lengkap dan bagus. Dengan demikian, adanya artikel ini penulis berharap dapat berbagi sumbangsih pemikiran dan pengalaman selama menggunakan media seesaw class learning management system . 
Twiningsih, A. (2021). Penggunaan Media Seesaw Class pada Kegiatan Belajar dari Rumah Selama Pandemi Covid-19. Edudikara: Jurnal Pendidikan dan Pembelajaran, 3(6), 163-175.

\section{SIMPULAN DAN SARAN}

Berdasarkan hasil dan pembahasan pelaksanaan penelitian yang sudah dilakukan, dapat disimpulkan bahwa keefektifan media seesaw class learning management system dalam kegiatan Belajar Dari Rumah (BDR) di masa Pandemi Covid-19 memberikan dampak positif terhadap efektifitas dan efisiensi kegiatan Belajar Dari Rumah pada peserta didik selama Pandemi Covid-19 (lihat grafik pada gambar 8). Selain itu, kreativitas guru dalam menciptakan strategi pembelajaran melalui media seesaw class learning management system pada pembelajaran secara daring bagi peserta didik memberikan peningkatan motivasi belajar dan perubahan terhadap iklim belajar. Penggunaan media seesaw learning management system juga memberi kemudahan bagi orang tua atau wali peserta didik dalam menerima instruksi tugas dari guru. Instruksi tugas dari guru yang biasa diberikan melalui whats app group yang terkadang bercampur dengan notifikasi lain yang masuk ke whats app group. Hanya saja penggunaan media seesaw class learning management system perlu memperhatikan kapasitas memori yang dimiliki hp androdi pengguna dan tentunya koneksi internet. Hal ini tidak lain karena mempengaruhi kelancaraan saat pengguna mengakses aplikasi media seesaw class learning management system.

\section{UCAPAN TERIMA KASIH}

Kami sebagai peneliti mengucapkan banyak terimakasih kepada keluarga besar SD Negeri Laweyan No. 54 Kota Surakarta, Bapak Ibu Guru, Kepala Sekolah, para Orangtua kelas 3 Serta siswa siswi kelas 3 yang telah berpartisipasi aktif dalam tercapainya kegiatan pelaksanaan Belajar Dari Rumah (BDR) selama masa Pandemi Covid-19, semoga dengan kerjasama dan kolaborasi yang baik antara sekolah dan orangtua siswa kegiatan pembelajaran tetap berjalan lancar meskipun selama Pandemi ini dilaksanakan secara daring.

\section{REFERENSI}

A. N, S., Bayu, Rani, \& Meidawati. (2019). Pengaruh Daring Learning terhadap Hasil Belajar IPA Siswa Sekolah Dasar Abstrak. In Seminar Nasional Sains \& Entrepreneurship (Vol. 1, pp. 1-5). Retrieved from

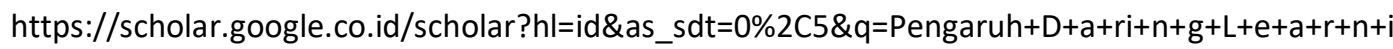
$+\mathrm{n}+\mathrm{g}+$ terhadapHasilBelajarIPASiswaSekolahDasar\&btnG $=$

Dewi, W. A. F. (2020). Dampak COVID-19 terhadap Implementasi Pembelajaran Daring di Sekolah Dasar. Edukatif : Jurnal Ilmu Pendidikan, 2(1), 55-61. https://doi.org/10.31004/edukatif.v2i1.89

Divayana, D. G. H., Heryanda, K. K., \& Suyasa, P. W. A. (2020). Pemberdayaan Pembelajaran Synchronous dan Asynchronous Berbasis Nilai-Nilai Aneka dalam Upaya Peningkatan Karakter Positif Siswa. In Proceeding Senadimas Undiksha ke-5, Septemnber 2020 (pp. 307-316).

Ebrahimzadeh, M., \& Alavi, S. (2017). The Effect of Digital Video Games on EFL Students' Language Learning Motivation. Teaching English with Technology, 17(2), 87-112.

Fahmi, M. H. (2020). Komunikasi Synchronous dan Asynchronous dalam E-learning pada Masa Pandemic Covid-19. Jurnal Nomosleca, 6(2), 146-158.

Fajri, M. (2017). Kemampuan Berpikir Matematis dalam Konteks Abad 21 di Sekolah Dasar. LEMMA (Letters of Mathematics Education), III(2), 1-11.

Harfiyani, A. (2018). Penguatan Pendidikan Karakter Melalui Budaya Literasi Dalam Konteks Pembelajaran Abad 21 Di Sekolah Dasar. In Prosding Seminar dan Diskusi Nasional Pendidikan Dasar 2018 (pp. 141-150).

Komara, E. (2018). Penguatan Pendidikan Karakter dan Pembelajaran Abad 21. SIPATAHOENAN: SouthEast Asian Journal for Youth, Sports \& Health Education, 4(1), 17-26. Retrieved from www.journals.mindamas.com/index.php/sipatahoenan

Martini, E. (2018). Membangun Karakter Generasi Muda Melalui Model Pembelajaran Berbasis Kecakapan Abad 21. Jurnal Pancasila Dan Kewarganegaraan, 3(2), 21-27. https://doi.org/10.24269/jpk.v3.n2.2018.pp21-27

Ningsih, S. (2020). Persepsi Mahasiswa terhadap Pembelajaran Daring pada Masa Pandemi Covid-19. 
Twiningsih, A. (2021). Penggunaan Media Seesaw Class pada Kegiatan Belajar dari Rumah Selama Pandemi Covid-19. Edudikara: Jurnal Pendidikan dan Pembelajaran, 6(3), 163-175

JINOTEP (Jurnal Inovasi Dan Teknologi Pembelajaran), 7(2), 124-132. https://doi.org/10.17977/um031v7i22020p124

Prananda, G., \& Hadiyanto. (2019). Korelasi antara Motivasi Belajar dengan Hasil Belajar Siswa dalam Pembelajaran IPA di Sekolah Dasar. Jurnal Basicedu, 3(3), 909-915.

Qotimah, K. (2018). Penerapan Aplikasi Seesaw Berbantuan Android untuk Meningkatkan Keaktifan dan Hasil Belajar IPS. In Seminar Nasional Optimalisasi Media Sosial dan Teknologi Informasi Sebagai Media Pengembangan Keprofesian Guru Berkelanjutan Karanganyar, 3 Juli 2018.

Sadikin, A., \& Hamidah, A. (2020). Pembelajaran Daring di Tengah Wabah Covid-19. Biodik: Jurnal Imiah Pendidikan Biologi, 6(2), 214-224. https://doi.org/10.22437/bio.v6i2.9759

Sobri, M., Nursaptini, \& Novitasari, S. (2020). Mewujudkan Kemandirian Belajar Melalui Pembelajaran Berbasis Daring Diperguruan Tinggi pada Era Industri 4.0. Jurnal Pendidikan Glasser, 4(1), 64-71. https://doi.org/10.32529/glasser.v4i1.373

Tantri, N. R. (2018). Kehadiran Sosial dalam Pembelajaran Daring Berdasarkan Sudut Pandang Pembelajar Pendidikan Terbuka dan Jarak Jauh. Jurnal Pendidikan Terbuka Dan Jarak Jauh, 19(1), 19-30. https://doi.org/10.33830/ptjj.v19i1.310.2018

Tegeh, I. M., Pratiwi, N. L. A., \& Simamora, A. H. (2019). Hubungan antara Motivasi Belajar dan Keaktifan Belajar dengan Hasil Belajar IPA Siswa Kelas V SD. Jurnal IKA, 17(2), 150-170.

Widiastiti, N. L. A., \& Sumantri, M. (2020). Model Quantum Teaching Berbasis Pendidikan Karakter terhadap Motivasi Belajar IPA. Jurnal Pedagogi Dan Pembelajaran, 3(2), 303-314. https://doi.org/10.23887/jp2.v3i2.26628 